
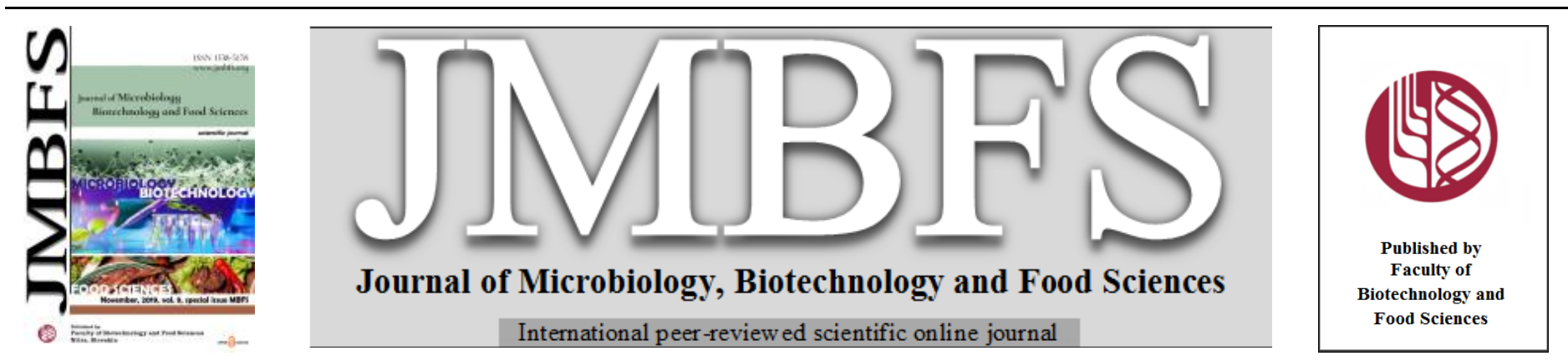

\title{
NUTRITIONAL AND TECHNOLOGICAL PROPERTIES OF SELECTED KINDS OF COFFEE
}

\author{
Eva Ivanišová ${ }^{* 1}$, Martina Czakóová ${ }^{\text {, Miroslava Kačániováa }{ }^{2,3}, \text { Eva Tvrdá }}$
}

Address(es):

${ }^{1}$ Department of Technology and Quality of Plant Products, Faculty of Biotechnology and Food Sciences, Slovak University of Agriculture in Nitra, Tr. A. Hlinku 2, SK-949 76.

${ }^{2}$ Department of Fruit Sciences, Viticulture and Enology, Faculty of Horticulture and Landscape Engineering, Slovak University of Agriculture in Nitra, Tr. A. Hlinku 2, SK-949 76.

${ }^{3}$ Department of Bioenergetics and Food Science, Faculty of Biology and Agriculture, University of Rzeszów, Zelwerowicza, St. 4, PL-35-601.

${ }^{4}$ Department of Animal Physiology, Faculty of Biotechnology and Food Sciences, Slovak University of Agriculture in Nitra, Tr. A. Hlinku 2, SK-949 76.

*Corresponding author: eva.ivanisova@uniag.sk

doi: 10.15414/jmbfs.2019.9.special.400-403

\section{ARTICLE INFO}

Received 11. 8. 2019

Revised 17. 10. 2019

Accepted 22. 10. 2019

Published 8. 11. 2019

Regular article

OPEN $\partial_{\text {ACCESS }}$

\begin{abstract}
The aim of the study was to evaluate the quality indicators (moisture content, fat, ash, polyphenols and antioxidant activity) of seven samples of green coffee. The coffee samples were subsequently roasted, using the cinnamon roasting style. In the prepared roasted coffee, the same measurements were made as in the green coffees, in order to compare the samples and point out the changes taking place during roasting. In addition, oxidative stability was determined after the roasting process. The moisture content of the green coffee ranged from $7.4 \%$ to $9.08 \%$, the ash content ranging from $2.53 \%$ to $2.97 \%$, the fat content from $2.19 \%$ to $6.33 \%$. The DPPH antioxidant activity ranged from 45.36 to $55.81 \mathrm{mg} \mathrm{TEAC.1}{ }^{-1}$ (TEAC - Trolox equivalent antioxidant capacity) and total polyphenols from 511.44 to $618.11 \mathrm{mg} \mathrm{GAE} . \mathrm{l}^{-1}$ (GAE - gallic acid equivalent). After the roasting process, the amount of dry matter $(97.88-98.54$ $\%)$ and fat $(3.38-12.76 \%)$ increased, the ash content did not change significantly. The most pronounced was the decrease in polyphenols, which is not surprising due to thermolabile substances. Overall, their values decreased of about $80 \%$ compared to green coffee samples. Despite these losses, the samples showed a high antioxidant activity after the roasting process -42.56 to $55.63 \mathrm{mg}$ TEAC. $1^{-1}$, which can be explained by the fact that during the roasting the Maillard reaction takes place, whereby new bioactive substances with antioxidant effect arise, on activity it also participates in vitamin $\mathrm{B}_{3}$, which is produced by thermal breakdown of trigonelline. The oxidative stability evaluated by the Rancimat method ranged from 1.2 to 10 minutes, suggesting that roasted coffee is susceptible to oxidation, therefore it should be milled just before preparation and serving.
\end{abstract}

Keywords: Coffea sp., roasting, fat, oxidative stability, antioxidant activity, polyphenols

\section{INTRODUCTION}

Coffee is considered the most important alimentary raw material in the world and is produced extensively in about 60 tropical and subtropical countries (Cruz et al., 2017). Coffee is a main dietary source of polyphenol and phenolic acid due to its high polyphenol and phenolic acid content. These constituent of the coffee are correlated well with high antioxidant properties, weight loss, mood enhancing and increase alertness, effectiveness against hypertension and anticancer properties. Recently, the demand and consumption of green coffee bean has skyrocket due to health properties contain in it (Zain et al., 2018). Green coffee beans are rich in the phenolic compounds exemplified by chlorogenic acid, caffeic acid, ferulic acid and $p$-coumaric acid. Coffee is the major source of chlorogenic acid in the human diet. On the basis of $10 \mathrm{~g}$ of coffee per cup of brew, a cup contains $15-325 \mathrm{mg}$ of chlorogenic acids; daily intake of coffee drinkers is $0.5-1.0 \mathrm{~g}$, whereas coffee abstainers typically ingest $<100 \mathrm{mg} /$ day (Votavová et al., 2009). Bioactive compound composition in coffee beans and coffee brew are highly dependent on the processing steps, and roasting is the most crucial of these steps. High temperature and low water activity in the roasting process facilitate molecular degradation and the formation of new compounds (Herawati et al., 2019). However roasting process introduced causes $8-10 \%$ chlorogenic acid degradation and transformation per each $1 \%$ loss of dry matter and $11 \%$ to $45 \%$ polyphenol degradation (Zain et al., 2018). The roasting process involves the application of heat to the beans ranging from 200 to $240{ }^{\circ} \mathrm{C}$ for a period of time that depends on the desired final product. There are three main levels in coffee roasting, light, medium, and dark. The main difference in the process is the time that the coffee remains in the roaster and this process can affect the composition of the coffee indifferent ways (Lerici and Nicoli, 1990). Roasting temperatures used, range from 160 to $240^{\circ} \mathrm{C}$ for durations of 8 to 24 minutes. The cinnamon (bright) type of roasting coffee is characterised by bright cinnamon-coloured grains with a matt surface, obtained by short roasting and/or at lower temperatures. Such a shortly roasted coffee gives a mildly spicy brew (Przybysz et al., 2013).

The aim of this study was to determine technological and nutritional properties of seven coffees (green and after roasting process) originating from various regions in order to elucidate changes and differences between green and roasting coffee.

\section{MATERIAL AND METHODS}

\section{Biological material and sample preparation}

The seven coffee samples - Elite (90\% Arabica+10\% Robusta), Forte (50\% Arabica+50 \% Robusta), Robusta India Kaapi Royal (100\% Robusta), Arabica Nicaragua Jinotega (100\% Arabica), Peru Jose Santos Campos (100\% Arabica), Tanzania Iyela PB (100\% Arabica), Kihungu United Uganda Rwenzori Mountains (100\% Arabica) were provided by the private supplier from Nitra (Slovakia). Green coffee (100 g) was fed to a micro-roaster coffee machine (Gene Café, CBR-101, Korea). The beans were roasted by using cinnamon roasting style $-235^{\circ} \mathrm{C}, 13$ minutes. Roasted coffee bean was ground in a grinder machine (Krups, GVX 2, Bur Grinder, Germany). Samples were ground to an average particle size (20 mesh), suitable for preparation in a paper filter. To prepare the extract, $0.1 \mathrm{~g}$ of sample was extracted with $20 \mathrm{ml} 95{ }^{\circ} \mathrm{C}$ distilled water, after 5 minute extraction filtered through filtrate paper (Whatman no 1) and used for analysis (antioxidant activity, total polyphenol content).

\section{Chemical}

All the chemicals used were of analytical grade and were purchased from SigmaAldrich (St. Louis, MO, USA) and CentralChem (Slovakia). 


\section{Technological and nutritional evaluation}

Moisture content and ash content were determined following the standard AACC method 08-01 (AACC 1996). Fat content was detected with Ancom XT15 Fat Extractor (USA) in line with producer instructions - the sample (1.5 g, W1) was weighted to special filter bag (XT4, Ancom, USA) and dried for 3 hours in an oven (WTB, Binder, Germany) at $105{ }^{\circ} \mathrm{C}$ to remove moisture prior to the extraction. Samples were placed in a desiccant pouch for 15 minutes and after re weighted (W2) and extracted 60 minutes at $90{ }^{\circ} \mathrm{C}$ with petroleum ether. After process samples were removed and dried in an oven at $105{ }^{\circ} \mathrm{C}$ for 30 minutes, placed in desiccant pouch and re-weighted (W3). Fat content $(\%)$ was calculated by following formula: $F C(\%)=[(W 2-W 3) / W 1] \times 100$.

The oxidative stability was determined in 892 Rancimat apparatus from Metrohm (Switzerland) according to ISO 6886:1997 utilizing a sample of $0.5 \pm 0.01 \mathrm{~g}$. All samples were studied in temperature $120{ }^{\circ} \mathrm{C}$, under a constant air flow $(20 \mathrm{~L} / \mathrm{h})$ The induction times were printed automatically by apparatus software with the accuracy of 0.005 .

\section{Antioxidant activity - DPPH method}

Antioxidant activity of samples was measured using 2,2-difenyl-1-picrylhydrazyl (DPPH) according to the procedures described by Sanchéz-Moréno et al. (1998). An amount of $0.4 \mathrm{ml}$ of extract was added to $3.6 \mathrm{ml}$ of DPPH solution (0.025 $\mathrm{g} \mathrm{DPPH}$ in $100 \mathrm{ml}$ ethanol). Absorbance of the reaction mixture was determined using the spectrophotometer Jenway (6405 UV/Vis, England) at 515 nm. Trolox (6-hydroxy-2,5,7,8-tetramethylchroman-2-carboxylic acid) (10-100 mg..$\left.^{-1} ; \mathrm{R}^{2}=0.989\right)$ was used as the standard and the results were expressed in $\mathrm{mg} .1$ 1 Trolox equivalents.

\section{Total polyphenol content}

Total polyphenol content was measured in accordance to Singleton and Rossi, (1965) using Folin-Ciocalteu reagent. A $0.1 \mathrm{ml}$ of sample was mixed with $0.1 \mathrm{ml}$ of the Folin-Ciocalteu reagent, $1 \mathrm{ml}$ of $20 \%(\mathrm{w} / \mathrm{v})$ sodium carbonate and $8.8 \mathrm{~m}$ of distilled water, and left in darkness for $30 \mathrm{~min}$. The absorbance at $700 \mathrm{~nm}$ was measured using the spectrophotometer Jenway (6405 UV/Vis, England). Gallic acid (25-300 mg..$\left.^{-1} ; R^{2}=0.998\right)$ was used as a standard and the results were expressed in $\mathrm{mg} . \mathrm{l}^{-1}$ of gallic acid equivalent.

\section{Statistical analysis}

All experiments were carried out in triplicate and the results reported are the results of those replicate determinations with standard deviations. The experimental data were subjected to analysis of variance (Duncan's test), at the confidence level of 0.05 , by the use of software SAS (2009).

\section{RESULTS AND DISCUSSION}

\section{Technological and nutritional evaluation of green coffee samples}

Moisture content (Tab. 1) of analyzed green coffee samples ranged from 7.4 to $9.08 \%$. Due to low level of moisture content coffee beans belong to stable crops, but this parameter must be monitored regularly. The bad storage condition a manipulation (especially higher moisture content) can cause growing of microscopic filamentous fungi in green beans. Viegas et al., (2017) in their study evaluated twenty-eight samples of green coffee (Arabica and Robusta) from different countries (Honduras, India, Costa Rica, Nicaragua) and found that the dominant contaminant in these samples was Aspergillus species (39\% Aspergillus niger and $29 \%$ Aspergillus circumdati). This microscopic filamentous fungus can produces mycotoxines, which are stable during roasting process, and can be poisonous for coffee consumer. From this reason is very important during the coffee processing to dry green coffee to required moisture content $10-12.5 \%$ and next storage in dry condition and lower air humidity.

Ash content in green coffee samples (Tab. 1) ranged from 2.53 to $2.97 \%$. In this work was determined total content of ash, but according to Farah, (2012) the dominant mineral element found in coffee is potassium. Its amount ranges from 1 to $2 \mathrm{~g} .100 \mathrm{~g}^{-1}$, which represents $40 \%$ of the total mineral content. Potassium is nutritionally important and is attributed to the ability to lower high blood pressure and also relieves muscle cramps (Hoffmann, 2014). In addition to potassium, phosphorus is also present in coffee beans in amount approximately $4 \%$. The coffee beans also content microelements presented in small amounts - iron, copper, zinc but also magnesium, the amount of which is greatly influenced by the soil on which coffee plants are grown. Coffee plants grown on volcanic soil, for example, are characterized by a higher content of these elements (especially iron, copper, magnesium).

Fat content (Tab. 1) in analyzed green coffee samples ranged from 2.19 to 6.33 $\%$. While the difference in moisture and ash content was minimal, the difference in the determination of fat was significant. For example in sample Robusta India Kaapi Royal was determined the amount of fat $2.19 \%$ which was also the lowest value; in sample Peru Jose Santos Campos the amount of fat was $6.33 \%$. The average amount of fat was $4.65 \%$.

\section{Antioxidant activity and total polyphenol content of green coffee samples}

Antioxidant activity determined by DPPH in analyzed samples of green coffee (Tab. 1) ranged from 45.36 to $55.81 \mathrm{mg}$ TEAC.1 ${ }^{-1}$. Sentkowska et al., (2016) similarly like in this study analyzed antioxidant activity (using DPPH method) of green coffee samples from different geographical origin. The samples of Arabica were from Brasil, Ruanda, China and Laos; samples of Robusta were from Vietnam, India, Indonesia, Laos and Uganda. The highest activity was determined in sample of Robusta from Laos $100 \mathrm{mg}$ TEAC. $1^{-1}$ and in the sample of Robusta from India $94.8 \mathrm{mg}$ TEAC. $\mathrm{I}^{-1}$. In samples of Arabica was detected lower antioxidant activity with compare to Robusta, with the highest values in sample of Arabica from Ruanda - 31.3 mg TEAC. $1^{-1}$ and from Brasil $28.3 \mathrm{mg}$ TEAC. $1^{-1}$. Our results are comparable with results obtained in this study. Antioxidant activity of coffee is very strongly influenced by agro ecological condition, soil and geographical condition (Sentkowska et al., 2016; Zain et al. 2018; Herawati et al., 2019). Coffee in our diet as a favorite soft drink plays an important role as it provides us with a significant amount of bioactive substances and thus contributes to the daily intake of antioxidants (Neduchalová, 2013).

The total polyphenol content (Tab. 1) in analyzed green coffee samples ranged from $511.44 \mathrm{mg} \mathrm{GAE} .1^{-1}$ to $618.11 \mathrm{mg} \mathrm{GAE} . \mathrm{l}^{-1}$. The highest value was detected in sample of Arabica Peru Jose Santos Campos, while the lowest value was determined in Arabica Tanzania Iyela PB. Similarly like antioxidant activity, amount of polyphenols in coffee beans is very strongly influenced by agro ecological condition, farming, soil and geographical condition (Sentkowska et al., 2016; Zain et al., 2018; Herawati et al., 2019).

\section{Technological and nutritional evaluation of roasted coffee samples}

Moisture content (Tab. 2) in analyzed roasted coffee samples (after roasting process - cinnamon roast) ranged from 1.46 to $2.12 \%$. After roasting process moisture content decreased, because due to high temperature the water content decreased, the volume of grains and friability increased - green coffee beans are hard, and it is almost impossible to chew them, but after the roasting process they are brittle and can be easily chewed. Thanking to the low moisture content the roasted coffee beans are stable product, but it should be properly stored, especially in a dry, well-closed packaging to avoid their contamination.

The ash content (Tab. 2) in analyzed roasted coffee samples (after roasting process - cinnamon roast) ranged from 2.95 to $3.26 \%$. Amount of total ash in analyzed samples was increased, but this can be explaining due to the fact that ratio of the moisture content and dry matter content was changed. Van Cuong $\boldsymbol{e t}$ al., (2014) determined the influence of roasting process (temperature $210{ }^{\circ} \mathrm{C}-20$ minutes, $220^{\circ} \mathrm{C}-18$ minutes, $230^{\circ} \mathrm{C}-14$ minutes, $240^{\circ} \mathrm{C}-12$ minutes and 250 ${ }^{\circ} \mathrm{C}-8$ minutes) to concentration of mineral elements - potassium, calcium and magnesium in Robusta coffee beans from Vietnam and results were compared with green coffee beans. The concentration of the individual elements increased with compared to green coffee and the highest concentration was reached at a roasting temperature of $250^{\circ} \mathrm{C}$. Potassium $(\mathrm{K})$, which was highest in green coffee, increased from $13.42-14.47 \mathrm{mg}$. $\mathrm{g}^{-1}$ to $13.84-15.09 \mathrm{mg}$. $\mathrm{g}^{-1}$. The concentration of calcium $(\mathrm{Ca})$ also increased from 0.77 to $1.26 \mathrm{mg}$. $\mathrm{g}^{-1}$. The actual composition and content of the individual mineral elements is different and their content mainly affects the profile of the soil in which the coffee plants were grown (ك̌arapatka, 2014).

Fat content (Tab. 2) in analyzed roasted coffee samples (after roasting process cinnamon roast) ranged from 3.38 to $12.76 \%$. The fat content of Arabica and Robusta coffee beans is different and ranges between 3-15\%. Arabica contains generally higher amount of fat which was confirmed also in our study, whereas amount of fat was the lowest in sample of Robusta India Kaapi Royal. The endosperm of coffee bean contains the largest proportion of fat, with only a small portion of the fat situated in the surface layers of the beans (Speer, 2006). In terms of coffee fat composition, it is predominantly a mixture of triacylglycerols, diterpenes and fatty acids. From the fatty acids, linoleic acid and palmitic acid are predominate, while from diterpenes are predominat cafestol and kahweol. These have been increasingly studied in recent years because of physiological effects on the human body. A recent study of the effects of coffee diterpenes on the migration of prostate cancer cells confirmed their beneficial effect. Kahweol and cafestol synergistically inhibit the proliferation and migration of prostate cancer cells, therefore these coffee compounds may represent a potential solution to treat prostate cancer problems (Hiroaki et al., 2018). The difference between Arabica and Robusta is mainly in the content of 16-O-methylcafestol, whose content has been determined only in Robusta, and therefore serves as a reliable indicator for the detection of Robusta in coffee mixtures (Speer, 2006).

Antioxidant activity (Tab. 2) in analyzed roasted coffee samples (after roasting process - cinnamon roast) ranged from 42.56 to $55.63 \mathrm{mg}$ TEAC. $1^{-1}$. From results can be possible to see, that after roasting process (high temperature) is still presence bioactive compounds in beans, which are responsible for antioxidant activity of coffee. A major contributor to the antioxidant activity was identified as $N$-methylpyridinium. The levels of $N$-methylpyridinium in roasted and ground 
coffee are positively correlated to the degree of roasting (Votavová et al., 2009) Methylpyridinium is not present in raw coffee beans but it is formed during the roasting process from its chemical precursor, trigonelline, which is common in raw coffee beans. Trigonelline is the second most abundant alkaloid in green coffee and reaches levels in Arabica and Robusta from 7.9 to $10.6 \mathrm{~g} . \mathrm{kg}^{-1}$ and from 6.6 to 6.8 g. $\mathrm{kg}^{-1}$, respectively (Stennert and Maier, 1994). Our results are comparable with the results of Neduchlová, (2013) which detected antioxidant activity by DPPH method in sample of Arabica Nicaragua Jinotega with value $50.52 \mathrm{mg}$ TEAC. $1^{-1}$ and in sample Robusta India Kaapi Royal - $41.01 \mathrm{mg}$ TEAC. $1^{-1}$

The total polyphenol content (Tab. 2) in analyzed roasted coffee samples (after roasting process - cinnamon roast) ranged from 93.67 to $126.44 \mathrm{mg}$ GAE. ${ }^{-1}$. Total polyphenols in roasted coffee significant decreased with compare to green coffee and this decrease was in level of $\sim 80 \%$ in all analyzed samples. Roasting evokes several changes in the constituents of coffee beans through modification or degradation. During roasting, high temperatures result in polypheno degradation. Chlorogenic, malic and citric acid levels become decreased, whilst quinic acid increases due to chlorogenic acid degradation. Thermal degradation of chlorogenic acid gives rise to phenolic compounds, such as chlorogenic acid lactones, which increase the bitter taste of coffee brews (Dybkowska et al., 2017). During roasting process chlorogenic acid decreased approximately from value $7 \%$ in green coffee to value $4.5 \%$ to roasted coffee. The content of chlorogenic acid varies from coffee to coffee, and the plant produces acid based on a number of stimuli, such as changes in climatic conditions or pest infestations. For this reason, the amount of chlorogenic acid in Robusta is higher because this coffee plant is better able to withstand weather fluctuations and is more resistant to external influences and pest infestations. Roasted Arabica coffee contains approximately $35-100 \mathrm{mg} 100 \mathrm{ml}^{-1}$ of chlorogenic acid and

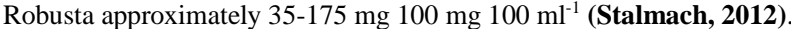

Oxidation stability (Tab. 2) of analyzed roasted coffee ranged from 1.2 to 10 minutes and results confirmed that coffee due to higher fat content is very sensitive for oxidation, especially after milling process. Therefore, mainly milled coffee should not be stored for a long time and if so in the dark, in the cold, well packaged especially in a vacuum package. However, skilled barists know that the best coffee is made from freshly ground beans. Grinding into the long-term storage of ground coffee is manifested by forming of unpleasant sensory compounds (oxidized, bitterness, "fish" odors).

Table 1 The results of moisture, ash, fat, total polyphenol content and antioxidant activity of analyzed green coffee samples

\begin{tabular}{|c|c|c|c|c|c|}
\hline Sample & $\begin{array}{c}\text { Moisture } \\
\text { content } \\
{[\%]}\end{array}$ & $\begin{array}{c}\text { Ash content } \\
{[\%]}\end{array}$ & $\begin{array}{c}\text { Fat content } \\
{[\%]}\end{array}$ & $\begin{array}{c}\text { Antioxidant } \\
\text { activity } \\
\left.\text { [mg TEAC. }{ }^{-1}\right]\end{array}$ & $\begin{array}{c}\text { Polyphenol } \\
\text { content } \\
{\left[\text { mg GAE.l }{ }^{-1}\right]}\end{array}$ \\
\hline Elite $(90 \%$ Arabica $+10 \%$ Robusta) & $9.01 \pm 0.02^{\mathrm{ab}}$ & $2.78 \pm 0.11^{\mathrm{ab}}$ & $5.50 \pm 0.21^{\mathrm{b}}$ & $45.36 \pm 0.35^{\mathrm{f}}$ & $577 \pm 1.12^{\mathrm{c}}$ \\
\hline Forte $(50 \%$ Arabica $+50 \%$ Robusta) & $8.88 \pm 0.03^{\mathrm{b}}$ & $2.8 \pm 0.09^{\mathrm{ab}}$ & $4.16 \pm 0.16^{\mathrm{d}}$ & $48.96 \pm 0.41^{\mathrm{d}}$ & $614.22 \pm 2.26^{\mathrm{b}}$ \\
\hline $100 \%$ Robusta India Kaapi Royal & $9.08 \pm 0.02^{\mathrm{a}}$ & $2.97 \pm 0.07^{\mathrm{a}}$ & $2.19 \pm 0.11^{\mathrm{e}}$ & $52.74 \pm 0.24^{\mathrm{b}}$ & $579.78 \pm 3.32^{c}$ \\
\hline $100 \%$ Arabica Nicaragua Jinotega & $8.76 \pm 0.06^{\mathrm{bc}}$ & $2.66 \pm 0.15^{\mathrm{bc}}$ & $4.17 \pm 0.09^{\mathrm{d}}$ & $46.89 \pm 0.12^{\mathrm{e}}$ & $554.78 \pm 2.98^{\mathrm{c}}$ \\
\hline $100 \%$ Arabica Peru Jose Santos Campos & $8.39 \pm 0.06^{\mathrm{cd}}$ & $2.55 \pm 0.17^{\mathfrak{c}}$ & $6.33 \pm 0.14^{\mathrm{a}}$ & $53.01 \pm 1.02 b$ & $618.11 \pm 2.45^{\mathrm{a}}$ \\
\hline $100 \%$ Arabica Tanzania Iyela PB & $8.27 \pm 0.01^{\mathrm{d}}$ & $2.53 \pm 0.11^{\mathrm{c}}$ & $4.79 \pm 0.14^{\mathrm{c}}$ & $51.03 \pm 1.06^{\mathrm{c}}$ & $511.44 \pm 1.11^{\mathrm{e}}$ \\
\hline $\begin{array}{l}100 \% \text { Arabica Kihungu United Uganda } \\
\text { Rwenzori Mountains }\end{array}$ & $7.4 \pm 0.02^{\mathrm{e}}$ & $2.81 \pm 0.05^{\mathrm{ab}}$ & $5.42 \pm 0.11^{\mathrm{b}}$ & $55.81 \pm 0.63^{\mathrm{a}}$ & $554.22 \pm 1.75^{\mathrm{c}}$ \\
\hline
\end{tabular}

TEAC - Trolox equivalent antioxidant capacity; GAE - gallic acid equivalent; \pm standard deviation; different letters in column denote mean values that statistically differ one from another

Table 2 The results of moisture, ash, fat, total polyphenol content, antioxidant activity and oxidation stability of analyzed roasted coffee samples

\begin{tabular}{|c|c|c|c|c|c|c|}
\hline Sample & $\begin{array}{c}\text { Moisture } \\
\text { content } \\
{[\%]}\end{array}$ & $\begin{array}{c}\text { Ash content } \\
{[\%]}\end{array}$ & $\begin{array}{c}\text { Fat content } \\
{[\%]}\end{array}$ & $\begin{array}{c}\text { Antioxidant } \\
\text { activity } \\
{[\text { mg TEAC.I-1] }}\end{array}$ & $\begin{array}{c}\text { Polyphenol } \\
\text { content } \\
{\left[\text { mg GAE. } \text { I }^{-1}\right]}\end{array}$ & $\begin{array}{c}\text { Oxidation } \\
\text { stability } \\
\text { [minutes] }\end{array}$ \\
\hline Elite (90\% Arabica +10 \% Robusta) & $2.12 \pm 0.12^{\mathrm{a}}$ & $3.19 \pm 0.14^{\mathrm{ab}}$ & $7.26 \pm 0.51^{\mathrm{d}}$ & $52.11 \pm 0.47^{b}$ & $107.56 \pm 5.03^{\mathrm{d}}$ & $3 \pm 0.05^{\mathrm{c}}$ \\
\hline $\begin{array}{l}\text { Forte (50\% Arabica }+50 \% \\
\text { Robusta) }\end{array}$ & $1.84 \pm 0.02^{\mathrm{bc}}$ & $3.37 \pm 0.12^{\mathrm{a}}$ & $5.25 \pm 0.33^{\mathrm{e}}$ & $44 \pm 1.51^{\mathrm{d}}$ & $93.67 \pm 3.52^{\mathrm{e}}$ & $7 \pm 1.12^{\mathrm{b}}$ \\
\hline $100 \%$ Robusta India Kaapi Royal & $1.87 \pm 0.04^{\mathrm{b}}$ & $3.37 \pm 0.07^{\mathrm{a}}$ & $3.38 \pm 0.09^{\mathrm{f}}$ & $42.56 \pm 0.22^{\mathrm{d}}$ & $126.44 \pm 2.92^{\mathrm{b}}$ & $10 \pm 0.84^{\mathrm{a}}$ \\
\hline $100 \%$ Arabica Nicaragua Jinotega & $1.81 \pm 0.15^{\mathrm{bc}}$ & $3.09 \pm 0.05^{\mathrm{ab}}$ & $9.09 \pm 0.32^{\mathrm{c}}$ & $53.56 \pm 0.99^{\mathrm{ab}}$ & $103.67 \pm 3.05^{\mathrm{d}}$ & $3 \pm 0.08^{c}$ \\
\hline $\begin{array}{l}100 \% \text { Arabica Peru Jose Santos } \\
\text { Campos }\end{array}$ & $2.04 \pm 0.11^{\mathrm{a}}$ & $2.95 \pm 0.14^{\mathrm{ab}}$ & $11.87 \pm 0.24^{\mathrm{b}}$ & $48.78 \pm 1.52^{\mathrm{c}}$ & $122.56 \pm 2.22^{\mathrm{bc}}$ & $1.2 \pm 0.05^{\mathrm{d}}$ \\
\hline $100 \%$ Arabica Tanzania Iyela PB & $1.71 \pm 0.08^{c}$ & $3.05 \pm 0.08^{\mathrm{b}}$ & $12.14 \pm 0.84^{\mathrm{b}}$ & $53.47 \pm 2.25^{\mathrm{ab}}$ & $118.67 \pm 3.05^{\mathrm{c}}$ & $1.2 \pm 0.63^{\mathrm{d}}$ \\
\hline $\begin{array}{l}100 \% \text { Arabica Kihungu United } \\
\text { Uganda Rwenzori Mountains }\end{array}$ & $1.46 \pm 0.07^{\mathrm{d}}$ & $3.26 \pm 0.17^{\mathrm{a}}$ & $12.76 \pm 0.27^{\mathrm{a}}$ & $55.63 \pm 1.63^{\mathrm{a}}$ & $137 \pm 2.84^{\mathrm{a}}$ & $2 \pm 0.85^{\mathrm{cd}}$ \\
\hline
\end{tabular}

TEAC - Trolox equivalent antioxidant capacity; GAE - gallic acid equivalent; \pm standard deviation; different letters in column denote mean values that statistically differ one from another

\section{CONCLUSION}

This study showed that roasting process of coffee had influence for nutritional and technological parameters of coffee beans. During the roasting process decreased amount of moisture content and total polyphenol content, while amount of fat and mineral compounds increased. Antioxidant activity of analyzed samples was not changed significantly due to the components which is forming due to Mailard's reaction and thanking to the degradation of trigonelline alkaloid. Results also showed, that roasted coffee due to higher amount of fat is very sensitive to oxidation, and so it is very important storage coffee with accordance to right storage conditions, especially ground coffee.

Conflicts of interest: All authors declare no conflicts of interest.

Acknowledgments: This work was co-funded by the KEGA project 009SPU4/2018 (90\%) and project 05-GA SPU-16 (10\%).

\section{REFERENCES}

AACC methods 8th, E.d. Methods 08-01, 44-05A, 46-13, 54-20. St. Paul, MN: American Association of Cereal Chemists.

CRUZ, R. G. da, VIEIRA, T. M. F. de S., \& LIRA, S. P. de. (2017). Potential antioxidant of brazilian coffee from the region of Cerrado. Food Science and Technology, 38(3), 447-453. http://dx.doi:10.1590/1678-457x.08017

DYBKOWSKA, E., SADOWSKA, A., RAKOWISKA, R., DEBOWSKA, M. SWIDERSKI, F., SWIADER, K. 2017. Assessing polyphenols content and antioxidant activity in coffee beans according to origin and the degree of roasting. Roczniki Panstwowego Zakladu Higieny, 68, 347-353

FARAH,A. 2012. Coffee constituents. In Yi-Fang,Chu. Coffe:Emerging health benefits and disease prevention. Hoboken: Wiley -blackwell, 21-58. ISBN 9780-470-95878-0.

HERAWATI, D., GIRIWONO, P. E., DEWI, F. N. A., KASHIWAGI, T., ANDARWULAN, N. 2018. Critical roasting level determines bioactive content and antioxidant activity of Robusta coffee beans. Food Science and Biotechnology, 28(1), 7-14. https://doi:10.1007/s10068-018-0442-x

HOFFMANN, J. 2014. The world atlas of coffee: From beans to brewing coffees explored, explained and enjoyed. London: Octopus Publishing Group 256 p. ISBN 9781845337872.

ISO 6886:1997. Animal and vegetable fats and oils-determination of oxidation stability (accelerated oxidation test). International Organization for Standardization, Geneva, Switzerland.

LERICI, C.R., NICOLI, M.C. 1990. Caffee: Aspecti chimici, technologici e qualita della bevanda/Coffee: Chemical, technological aspects and quality of the drink. Rivista della Societa Italiana di Scienta dell'Alimentatione, 19, 1-16.

NEDUCHALOVÁ, M. 2013. Stanoveni biologicky aktivních látek v různých druzich kávy/Determination of bioactive compounds in different kind of coffees: Diploma work. Zlín: Tomas Bata University in Zlin. 71 p.

PRZYBYSZ, M.A., WIDLA, G., DLUŽEWSKA, E. 2013. Consumer prefers on coffee drinking. The influence of temperature and roasting time of coffee bean on espresso aroma and taste. Zeszyty Problemowe Postepów Nauk Rolniczych, 572, 65-79.

SÁNCHÉS-MORENO, C., LARRAURI, A., SAURA-CALIXTO, F. 1998. A procedure to measure the antioxidant efficiency of polyphenols. Journal of Science and Food Agriculture, 76, 270-276. 
ŠARAPATKA, B. 2014. Pediologie a ochrana půdy/ Pedology and soil protection. Olomouc: Palacky University in Olomouc. 232 p. ISBN 978-80-2443736-1.

SAS 2009. Users Guide Version 9.2. SAS/STAT (r) SAS Institute Inc. Cary, NC, USA.

SETKOWSKA,A., JESZKA-SKOWRON, M., PYRZYNSKA,K. 2016. Comparative Studies on the Antioxidant Properties of Different Green Coffee Extracts. MOJ Food Processing \& Technology, 3(2), 296-302. https://doi:10.15406/mojfpt.2016.03.00071

SINGLETON, V.L., ROSSI, J.A. 1965. Colorimetry of total phenolics with phosphomolybdic-phosphotungstic acid reagents. American Journal of Enology and Viticulture, 6, 1444-158.

SPEER, K., KÖLLING-SPEER, I. 2006. The lipid fraction of the coffee bean Brazilian Journal of Plant Physiology, 18(1), 201-216. http://dx.doi:10.1590/s1677-04202006000100014

STALMACH, A. 2012. Bioavailability of Coffee. In Yi-Fang,Chu. Coffe : Emerging health benefits and disease prevention. Hoboken: Wiley -blackwell, 65-84. ISBN 978-0-470-95878-0.

STENNERT, A., MAIER, H.G. 1994. Trigonelline in coffee. Zeitschrift für Lebensmittel-Untersuchung und -Forschung, 199, 198-200.

VAN CUONG, T., HONG LING, L., KANG QUAN, G. 2014. Effect of roasting conditions on concentration in elements of Vietnam Robusta coffee. Acta Universitatis Cibiniensis. Series E: Food Technology, 18(2), 19-34. https://doi:10.2478/aucft-2014-0011

VIEGAS, C., PACIFICO, C., FARIA, T., DE OLIVEIRA A., CAETANO, L. CAROLINO, E., GOMES, A., VIEGAS, S. 2017. Fungal contamination in green coffee beans samples: A public health concern. Journal of Toxicology and Environmental Health, Part A, 80(13-15), 719-728. https://doi:10.1080/15287394.2017.1286927

VOTAVOVÁ L VOLDŘICH, M ŠEVČÍK, $R$ ČÍŽIKOVÁ, $H$, MLEJNECKÁ, J., STOLǍ̌, M., FLEIŠMAN, T. 2009. Changes of antioxidan activity of Robusta coffee during roasting. Czech Journal of Food Sciences, 27(Special Issue 1), S49-S52. https://doi:10.17221/1105-cjfs

ZAIN, M.Z.M., BABA, A.S., SHOR, A.B. 2018. Effect of polyphenol enriched from green coffee bean on antioxidant and sensory evaluation of bread. Journal of King Saud University - Science, 30(2), 278-282. https://doi:10.1016/j.jksus.2017.12.003 